
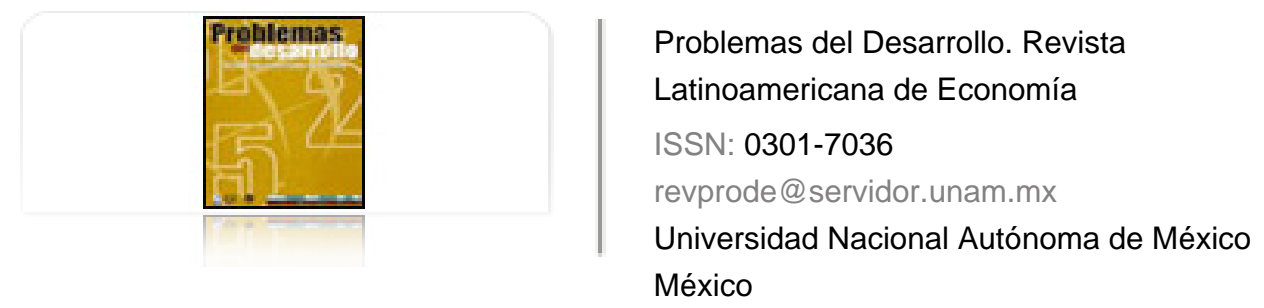

Zhong, Xiwei; Yang, Jianmin

THE U/RI-INDUSTRY LINKAGE AND THE DEVELOPMENT OF THE COMPUTER INDUSTRY IN CHINA

Problemas del Desarrollo. Revista Latinoamericana de Economía, vol. 37, núm. 147, octubrediciembre, 2006, pp. 161-186

Universidad Nacional Autónoma de México

Distrito Federal, México

Disponible en: http://www.redalyc.org/articulo.oa?id=11820100007

Cómo citar el artículo

Número completo

- Más información del artículo

Página de la revista en redalyc.org

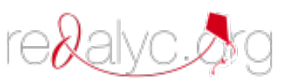

Sistema de Información Científica

Red de Revistas Científicas de América Latina, el Caribe, España y Portugal Proyecto académico sin fines de lucro, desarrollado bajo la iniciativa de acceso abierto 


\section{The U/Ri-industry Linkage AND the Development of THE COMPUTER INDUSTRY IN CHINA}

\section{Xiwei Zhong* Jianmin Yang**}

Fecha de recepción: 5 de abril de 2006. Fecha de aceptación: 3 de septiembre de 2006.

\section{Abstract}

This paper reviews the innovation of the S\&T system during recent years in China, analyzes the university/research institute-industry (U/RI-industry) linkage and discusses the role of U/RI-industry linkage in the development of China's computer industry. The paper shows that universities and research institutes have become the driving force in the development of high-tech sectors in China by the case studies of the U/RI-industry linkage in computer industry. It proposes that developing countries follow China's experience of building indigenous innovative capacity by strengthening the U/RI-I linkage under adequate guidance of the government policy.

Key words: U/RI-industry linkage; S\&T system; URIs; computer industry; universityaffiliated enterprises

* Post doc research fellow at the Instituto de Investigaciones Económicas of Universidad Nacional Autónoma de México (UNAM), associate professor of College of Economic of Huazhong University of Science \& Technology of People's Republic of China. E mail: xiweizhong2002@yahoo.com.cn

** Visting scholar at Centro Coordinador y Difusor de Estudios Latinoamericanos (CCYDEL) of UNAM, assitant researcher at Academia of Social Science of China(CAss). E mail: proxyang@hotmail.com. 
Resumen

Este trabajo analiza la innovación del sistema de ciencia y tecnología en años recientes en China. Analiza la relación entre Universidad/Instituto de investigación-industria (U/RI-industry) y debate el papel de ésta en el desarrollo de la industria de la computación de China. Asimismo demuestra que las universidades y los institutos de investigación han llegado a ser la fuerza que impulsa el desarrollo de los sectores de alta tecnología en China mediante el estudio de caso de esta relación en la industria de la computación. Se propone que los países en vías de desarrollo sigan la experiencia china de construir capacidades propias de innovación a través del reforzamiento de la conexión universidad/instituto de investigación-industria bajo la adecuada planificación de políticas gubernamentales.

Palabras clave: universidad/instituto de investigación-industria; sistema de ciencia y tecnología; universidades e institutos de investigación; industria de la computación, universidad-empresas afiliadas.

\section{Résumé}

Ce travail est une analyse de l'innovation que constitue le système de science et de technologie adopté en Chine ces dernières années. Il examine la relation entre université/institut de recherche et industrie (U/RI-industry) et traite du rôle joué par cette relation dans le développement de l'industrie informatique chinoise. Il y est démontré, à travers l'étude de ce cas précis, que les universités et les instituts de recherche sont parvenus à constituer la force qui impulse le développement des secteurs de haute technologie en Chine. Il est proposé enfin que les pays en voie de développement prennent modèle sur l'expérience chinoise de construction de ses propres capacités d'innovation sur la base du renforcement de la connexion université/institut de recherche-industrie, et planifient des politiques gouvernementales à cet effet.

Mots-cléfs: université/institut de recherche-industrie; système de science et de technologie; universités et instituts de recherche; industrie informatique; universités et entreprises affiliées.

\section{Resumo}

Este trabalho analisa a inovação do sistema de ciência e tecnologia em anos recentes na China. Analisa a relação entre Universidade/Instituto de investigação-indústria (U/RI-industry) e debate o papel desta no desenvolvimento da indústria da computação da China. Demonstra também que as universidades e os institutos de investigação se tornaram a força que promove o desenvolvimento dos setores de alta tecnologia na China através do estudo de caso desta relação na indústria da computação. Propõe-se que os países em vias de desenvolvimento sigam a experiência chinesa de construir capacidades próprias de inovação através do reforço da conexão universidade/instituto de investigação-indústria sob a adequada planificação de políticas governamentais.

Palavras chave: universidade/instituto de investigação-indústria; sistema de ciência e tecnologia; universidades e institutos de investigação; indústria da computação, universidades-empresa filiadas. 
Introduction

in recent years, China's computer industry has undergone amazing

development. Domestic enterprises have been achieving great success in this

area. One prominent feature is that the country's own capacity to build the computer industry has been closely linked with public research institutes and universities. The reform of China's innovation system since the 1980s has strengthened the U/RI-industry (university/research institute-industry) linkage and propelled research institutes and universities to play a key role in the hi-tech sectors in China.

The concept of innovation system has been adopted to explain mechanisms of knowledge creation and dissemination at national, regional or sectoral levels (Freeman, 1987; Lundvall, 1992, Nelson, 1993; Saxenian, 1994; Edquist, 1997; Breschi and Malerba, 1997). A primary focus of these studies is the role of different players in innovative activities and the interaction of these players. In particular, many have focused on the roles of universities and research institutes in the division of labor in national innovation systems and their linkages with the industry in fulfilling these roles.

In developed nations, it is now widely accepted that universities and research institutes (URIs) have played a significant role in the regional development of hightech industries. In the us, the two most successful clusters of hi-tech firms in both the information technologies and biotechnologies are the Boston and San Francisco Bay areas (Kenny, 1986). The success of these two regions can be, at least, partially explained by the presence of global-ranking universities. Not surprisingly, the discussions of high technology regions have focused on the developed nations, though recently Bresnahan and Gambardella (2004) edited a book on hi-tech regions including an examination of Hsinchu (Saxenian, 2004) and a general discussion of India (Arora, Gambardella, and Torrisi, 2004). Hardly anyone has looked into these issues in the settings of China, the biggest developing country in the world.

In this paper, I will put the discussion of the development of China's computer industry within the context of the 20 years' dramatic reform of China's innovation system and highlight the role of U/RI-industry linkage in indigenous innovative capacity-building through a detailed introduction of those leading enterprises in the information technology (гт) sector. In the next section, I will first give a brief review of the literature on the U/RI-industry linkage. After the brief overview, I shall move on to introduce China's 20 years' reform of the Science \& Technology 
(S\&T) system and the current status of the U/RI-industry linkages. The development of China's compute industry will be carefully analyzed thereafter and a conclusion will be drawn at the end.

\section{A review of the literature}

In the knowledge economy, URIs are considered vital actors in the creation, acquisition, dissemination, and utilization of knowledge in a national innovation system (Nelson and Rosenberg, 1993). The literature broadly defines the NIs (National Innovation System) as a network of institutions, policies, and agents supporting and sustaining scientific and technical advance (Nelson and Rosenberg, 1993; Porter and Stern, 2001; Furman et al. 2002; Crow and Boeman, 1998). Three core actors in the NIS are URIS (university and research institutes), industry, and often, the government (Etzkowitz, 1999; Mowery and Rosenberg, 1993).

Generally speaking, U/RI-industry relations include: labor market-related linkages, linkages for the creation, acquisition and dissemination of knowledge, and linkages to create new enterprises that form the basis of hi-tech regions. URIS are the major educational and training institutions within which educated and trained students and professionals gain knowledge and skills to become a part of the labor pool in national and regional economies (Jaffe, 1989). More specifically, linkages between URIS and industry take a variety of forms, such as joint R\&D projects, technology licensing, consulting, internships, and other collaborations between firms and URIs, to develop the products or the technology (Kodama and Branscomb, 1999).

More recently, there has been much interest in the role of universities and research institutes as a source of spin-offs. There is substantial evidence that universities around the world are adopting a policy of encouraging entrepreneurship (Rappert et al., 1999; Shane, 2003; Goldfarb and Henrekson, 2003). Framed in a slightly different way, Etzkowitz et al. (2000) observed that the university as an institution is moving toward a more entrepreneurial paradigm. But theoretically, while there is a consensus on the role of the university in disseminating knowledge through teaching activities, there are certain disagreements about its role in generating knowledge, and even less agreement on its linkage to the industry and the commercial market. Dasgupta and David (1994) presented an economic argument which also favors keeping academic and industrial research separate. They argue that industrial research focuses on profit and intellectual property, while academic research should concern itself more with fundamental discovery. Mixing the two would distort resource allocation and hence, have negative social welfare implications.

China developed a policy of encouraging the spin-off of enterprises from universities and research institutions, even while owning the spin-offs. In 
particular, university-affiliated enterprises, along with those hi-tech enterprises affiliated with government research institutes, have grown into a major force in China's hi-tech industry. ${ }^{1}$ Whether such academia-industry linkage is appropriate or not, such enterprises have made a unique contribution to the development of hitech industry in China. To analyze this phenomenon, we should look into the historical background within which the U/RI-industry linkages have evolved.

\section{The innovation of China's s\&T system}

The evolution of government policy

Since the 1980s, China's S\&T system has undergone significant reforms. China's slogan for the S\&T reform 1985, "build the nation with science and education", shows that education and scientific research served as a key to the development of the country. Since then, universities and research institutions have worked actively to collaborate with industry. Since the 1990s, as well as being involved in different kinds of collaboration with enterprises, universities and research institutions have been encouraged to establish their own enterprises, especially in the hi-tech sectors.

The reform since 1985 can be divided into 3 stages and each stage is symbolized by important policies issued by the government. The first stage was from 1985 to 1992. The central government issued a decree on structural reform in the education system, "Resolution of the Central Committee of the Communist Party of China on Structural Reform in Educational System" (CCCP, 1985), which emphasized the role of the university in the development of S\&T in China. Almost at the same time, another decree "Resolution of the Central Committee of the Communist Party of China on the Reform of the S\&T System" was issued. It propelled the reform of the S\&T system and encouraged universities and research institutes to strengthen their linkage with industry (мозт, 1999). The budget for the funding of research institutes and universities was cut considerably with a view to stimulating research institutes and universities to turn to industry for their survival. To facilitate this process, regulations and laws concerning patenting and technology transfer were issued to facilitate the linkage between URIS and industry.

The second stage was from 1992 to 1999. Since Deng Xiaoping's southern tour in 1992, the transformation of China's economic system has entered a new stage. The most important characteristic of this stage is that the government has begun to

1 There is no universally accepted definition of high-tech industry. This paper accepts the Chinese definition of "high - tech industry", generally including electronics and IT technology, space science and aeronautics, optical technology, life sciences, materials science and new material energy resources, ecology and environmental science, medical science, etc. 


\section{XIWEI ZHONG Y JIANMIN YANG}

render more operational autonomy to government-owned institutions and universities. The State Council issued its endorsement of university/research institute - affiliated (URI-affiliated) enterprises in a document submitted by the Education and Science Commissions to provide guidelines for administering university-run enterprises in 1991. University and government-owned institutes are encouraged to establish different forms of linkage with enterprises, including technical services, cooperation in development, production and management, as well as technology investment, etc. They are also encouraged to establish their own hi-tech enterprises. Researchers and college teachers can take part-time or full-time research jobs in enterprises or establish their own hi-tech enterprises while continuing to hold on to their posts. Statistics indicated that from 1997 to 2000, the average growth rate of sales income for university-affiliated enterprises (UAEs) had reached $32.3 \%$ annually. Up to 2000, there had emerged 2097 hi-tech university-run enterprises in China with net assets of US\$ 3.8 billion (MOST, 2001).

The third stage started from the year 1999 and has continued until today. The emphasis of the policy is on promoting the transformation of research institutes and elevating the innovation capacity of industry during this period. Since 1999, China began to transform government-owned applied research institutes into hi-tech enterprises or technical service enterprises. At the national level, the first batch of 242 research institutes affiliated to the former State Committee for Economics and Trade were transformed into enterprises. By the end of 2003, 1149 formerly government-owned research institutes had been transformed into independent enterprises. The rest of them have been transformed into non-enterprise institutes, such as parts of universities or other research institutes or intermediate agencies. The government applied more active plans for the development of Science Parks, which were regarded as a "key component" of the national innovation system. Measures and laws to establish technology transfer were promulgated. A series of regulations or decrees was issued to facilitate technological innovation. The government began to examine deeply the efficiency of URI-affiliated enterprises in 2001. Since then, the "de-linkage" of URIS and their affiliated enterprises has been under progress.

The effects of sET reform: strengthening U/RI-industry linkage

During the 20-year reform, the mechanism for cooperation between industry, universities and research institutes was established. In 2003, enterprises were engaged in $90 \%$ of all the projects in the national S\&T program for key R\&D technologies, mostly in cooperation with universities and research institutes. $80 \%$ of the large enterprises have established ties with URIS (MOST, 2003). 
Comparing the profile of China's innovation system in 1987 and 2003, we find dramatic differences. The 1987 innovation system followed the model of a strong centralized administration. Public research institutes (PRIS, actually there were no private ones) conducted the majority of the R\&D projects, funded mainly by either central or local government; universities were mainly responsible for education with limited involvement in R\&D; enterprises rarely had any input in the projects of the research institutes and they were responsible for limited downstream innovation activities concerning their production and prototyping. Under such a system, researchers in PRIS and universities had little incentive to conduct productive research and transfer their research results to commercial applications.

In 2003, things changed a lot. Compared with 1987, the total R\&D expenditure increased by more than 8 times; the R\&D expenditure of universities was raised from $4 \%$ to $10.5 \%$; personnel involved in public research institutes declined considerably while those in enterprises increased to a larger extent.

The rapid increase in R\&D personnel and expenditure on the part of enterprises can be explained as follows. First, the transformation of former public research institutes added to the personnel and R\&D ability of the enterprises. Among the 1149

Table 1

A profile of China's innovation system 1987

\begin{tabular}{lcccc}
\hline $\begin{array}{l}\text { Types of R\&D } \\
\text { Institutions }\end{array}$ & $\begin{array}{c}\text { Number of R\&D } \\
\text { Institutes }\end{array}$ & $\begin{array}{c}\text { R\&D Personnel } \\
\text { (in } 1000 \text { person/year) }\end{array}$ & \multicolumn{2}{c}{$\begin{array}{l}\text { R\&D Expenditures } \\
\text { (in million US\$, \%) }\end{array}$} \\
\hline $\begin{array}{l}\text { Public Research Institutes } \\
\text { Universities' R\&D Units }\end{array}$ & 5222 & 386 & 2886.5 & $(60.7)$ \\
Enterprises' R\&D Units & 934 & 178 & 189.2 & $(4)$ \\
\hline Total & 5021 & 253 & 1678.4 & $(35.3)$ \\
\hline
\end{tabular}

Source: compiled by the authors from www.sts.org.cn

Table 2

A profile of China's innovation system in 2003

\begin{tabular}{lrcrr}
\hline \multicolumn{1}{c}{$\begin{array}{c}\text { Types of R\&D } \\
\text { Institutions }\end{array}$} & $\begin{array}{c}\text { Number of R\&D } \\
\text { Institutes }\end{array}$ & $\begin{array}{c}\text { R\&D Personnel } \\
\text { (in 1000 person/year) }\end{array}$ & \multicolumn{2}{c}{$\begin{array}{c}\text { R\&D Expenditures } \\
\text { (in million US\$, \%) }\end{array}$} \\
\hline Public Research Institutes & 4169 & 204 & 4807.2 & $(25.9)$ \\
Universities' R\&D Units & 3200 & 189 & 1955.4 & $(10.5)$ \\
Enterprises' R\&D Units & 11300 & 478 & 11568.7 & $(62.4)$ \\
Others & 3300 & 62 & 218.1 & $(1.2)$ \\
\hline Total & 21969 & 933 & 18549.4 & $(100)$ \\
\hline
\end{tabular}

Source: compiled by the authors from www.sts.org.cn 
research institutes that were transformed, 1003 have become enterprises or parts of enterprises, which added up to a total enterprise S\&T personnel increase of 102,000. The U/RI-run enterprises, a lot of them involved in hi-tech sectors, also increased the R\&D density of this category. Secondly, with the enforcement of a liberalization policy since 1980 s, the market has been getting more and more competitive, which stimulates the initiative of $R \& D$ activities at the enterprises. Thirdly, the S\&T reform that concentrates on promoting a favorable environment-supporting R\&D and deepened U/RI linkage has also helped to build up the R\&D potential of the enterprises.

China's innovative capacity has also expanded rapidly. In terms of publications listed in SCI, EI and ISTP, China improved from 15th in 1990 to fifth in 2003, with 93352 publications listed. In respect to patent applications, from 2000 to 2003, the number of all three types of patent applications were on the rise. Before 2003, foreigners were more active than the Chinese in invention patenting. In the year 2003, Chinese patent applications increased greatly and for the first time in the 4 years from 2000 to 2003 surpassed their foreign counterparts' applications. Table 3 shows the distribution of the sources of invention patents approved from 1996 to 2002. Since 2000, Chinese companies have overtaken public research institutes to become the most important contributors in the domestic invention patenting market. Patents approved for enterprises have been rising sharply, especially since 2000. The drop experienced by research institutes in 2000 occurred because many research institutes began their transformation at that time.

The transformation of the research institutes has changed the research model of the research institutes from government-oriented to market-oriented. It is beneficial

Table 3

Invention patents approved (1996-2002)

\begin{tabular}{lrrrrrrr}
\hline & 1996 & 1997 & 1998 & 1999 & 2000 & 2001 & 2002 \\
\hline Domestic & 1383 & 1532 & 1655 & 3097 & 6177 & 5395 & 5868 \\
Professional & 825 & 912 & 954 & 1685 & 2824 & 2614 & 3144 \\
Universities & 228 & 256 & 243 & 425 & 652 & 579 & 697 \\
Research institutes & 247 & 316 & 337 & 543 & 910 & 800 & 907 \\
Enterprises & 187 & 170 & 182 & 462 & 1016 & 1089 & 1461 \\
Government & & & & & & & \\
$\quad$ organization & 163 & 170 & 192 & 255 & 246 & 146 & 79 \\
Non-professional & 558 & 620 & 701 & 1412 & 3353 & 2781 & 2724 \\
Foreign & 1593 & 1962 & 3078 & 4540 & 6506 & 10901 & 15605 \\
Professional & 1497 & 1889 & 2949 & 4295 & 6222 & 10455 & 15013 \\
Non-professional & 96 & 73 & 129 & 245 & 284 & 446 & 592 \\
\hline Total & 2976 & 3494 & 4733 & 7637 & 12683 & 16296 & 21473 \\
\hline
\end{tabular}

Source: compiled by the authors from http://www.sts.org.cn 
to build up their indigenous technology innovation capacities. The transformed research institutes still play a very important role in industrial progress. They have been taking over a lot of national science and technology programs and provide technological services to the enterprises. From the perspective of reform, of the 1149 transformed research institutes, 1003 have become enterprises or parts of enterprises. Those remaining state-owned research institutes have increased their expenditure on R\&D. The coverage of R\&Dexpenditure in the total S\&T expenditure of research institutes has increased from $40 \%$ in 1985 to $65 \%$ in 2003, which shows that public research institutions have had more incentives to carry out technology innovation work than before.

Universities have become a significant base for knowledge generation, diffusion, technology innovation, and the commercialization of S\&T achievement. Patent applications by universities in 2003 registered a $150 \%$ increase over 2002; the R\&D expenditure of universities accounted for $10.2 \%$ of the total R\&D expenditure of 2003. In particularly, the growth of UAEs is striking. Before 1985, some universities only had their own university-affiliated factories, used only for students to obtain short-term internships or apprenticeships. Currently, there are more than 4000 UAES and some of them, especially in the IT sector, have developed themselves into strong competitors of their multinational counterparts in the domestic or global market.

Generally speaking, the S\&T reform has been effective in promoting S\&T in the economy and building up an indigenous capacity for the industry. The government's role of facilitating and orienting S\&T development has been rather successful. If we look into the policy in depth, we may find two factors which are combined to give incentives to the research institute and universities. On the one hand, the government budget for research institutes and universities has been greatly reduced since 1985, putting them in a difficult financial situation. It has become crucial for Chinese URIS to secure funds from other sources. On the other hand, the government gave research institutes and universities legally independent status and pushed them to develop ties with industry through various kinds of support, such as offering favorable policies, opening up the technology transfer market, establishing a hi-tech development zone and science parks, etc. As a result, the developing linkage with industry has become a very attractive way for many uRIs to finance their operations. Take Huazhong University of Science \& Technology, a famous university of engineering for example. Its income from government appropriations had decreased from $60 \%$ to $30 \%$ from 1985 to 2003, while income from research had increased from $20 \%$ to $40 \%$, largely the result of increasing research funds from enterprises, including its own affiliated enterprises. 
An overview of u/RI-industry linkages in China

Since 1985, R\&D from enterprise sources has increased rapidly. As we can see from table 3, in 1985, the government provided $79 \%$ of the R\&D funds, while in 2000 only $33.4 \%$. Statistics for 2003 show that enterprises provided $60.2 \%$ of all the funds raised and the government $29.9 \%$, a $3.5 \%$ decrease compared with the year 2000. Enterprises have become the most important investors in R\&D activities.

Since the 1985 S\&T system reform, universities and research institutes (transformed or public ones) have made great efforts to develop closer ties with industry. In China, the U/RI-industry linkages include informal consulting of university researchers in industry, technology service contracts, joint research projects, science parks, university-run enterprises and more recently, patent licensing.

Of all the forms of linkage, technology service contracts have become a major source of research funding for research institutes and universities. In research institutes and universities, researchers are highly motivated to look for cooperation from enterprises by signing technology service contracts. An examination of the R\&D spending of Chinese universities (see table 4 ) reveals that a very high percentage of their spending is on applied and experimental research (more than 80 percent). It is expected that most of this spending is funded by industry through different forms of technology contracts.

Professors and researchers can use different methods to obtain projects: funds from different level of government, university projects, and, of particular importance, companies. Since the competition for government project is usually very high,

Table 4

$R \& D$ expenditure of universities

(1991-2002, 100 million yuan RMB, \% -1991-2002, million USD, \%—)

\begin{tabular}{lllllllll}
\hline $\begin{array}{l}R \& D \\
\text { expenditure }\end{array}$ & \multicolumn{2}{c}{$\begin{array}{c}\text { Basic } \\
\text { research }\end{array}$} & \multicolumn{2}{c}{ Applied research } & \multicolumn{2}{c}{$\begin{array}{c}\text { Experimental } \\
\text { research }\end{array}$} & \multicolumn{2}{c}{ Total } \\
\hline 1991 & 24.5 & $(13.9)$ & 143.4 & $(55.5)$ & 81.1 & $(31.4)$ & 249 & $(100)$ \\
1992 & 43.6 & $(12.5)$ & 183.6 & $(52.6)$ & 120 & $(34.4)$ & 347.2 & $(100)$ \\
1993 & 58.6 & $(12.2)$ & 258.7 & $(53.6)$ & 164.9 & $(34.2)$ & 482.2 & $(100)$ \\
1994 & 59.3 & $(13.2)$ & 248.8 & $(55.3)$ & 140.7 & $(31.3)$ & 448.8 & $(100)$ \\
1995 & 77.8 & $(15.4)$ & 279 & $(55.1)$ & 149.7 & $(29.6)$ & 506.5 & $(100)$ \\
1996 & 90.4 & $(15.7)$ & 321.7 & $(55.9)$ & 165.1 & $(28.7)$ & 577.2 & $(100)$ \\
1997 & 116.9 & $(16.8)$ & 380.7 & $(54.8)$ & 197.6 & $(28.4)$ & 695.2 & $(100)$ \\
1998 & 104.8 & $(16)$ & 367.5 & $(56.1)$ & 184.3 & $(28.1)$ & 656.6 & $(100)$ \\
1999 & 137.3 & $(18.0)$ & 454.2 & $(59.4)$ & 173.5 & $(22.7)$ & 765 & $(100)$ \\
2000 & 214.5 & $(23.2)$ & 481.9 & $(52.1)$ & 227.7 & $(24.7)$ & 924.1 & $(100)$ \\
2001 & 204.8 & $(16.6)$ & 710.8 & $(57.6)$ & 318.1 & $(25.8)$ & 1233.7 & $(100)$ \\
2002 & 334.9 & $(21.3)$ & 808.4 & $(51.5)$ & 428.9 & $(27.2)$ & 1572.2 & $(100)$ \\
\hline
\end{tabular}

Source: compiled by the authors form China Statistical Yearbook 1992-2003, National Bureau of Statistics of China). 
projects from companies have become very attractive. Generally, professors return a certain amount of the funding to universities/departments (5\%-20\%) as "maintenance fees", while the rest of the money can be used very autonomously by themselves. Besides this, projects bring professors and researcher many other benefits, including promotion and prizes.

As we have seen in table 3, patenting activity in China has been relatively weak, but the trend during recent years shows that the Chinese are becoming more likely to patent inventions. Income generated by Chinese universities through licensing and sales of patents in 2002 was 11 times what it was in 1985 (Liu, 2006). Universities and research institutes have begun to pay more attention to intellectual property issues. Many of them have set up technology transfer offices to promote the commercialization of intellectual properties generated by universities.

The first university-based science park was established by Northeast University in 1988. Up to 2003, there were 44 university-based science parks. They are typically created by the joint effort of local government and university administration. Most of these parks are located on or adjacent to the university campus and administered by a commercial entity established by the university or through a joint venture between local government and the university. The park administration not only manages the real estate of the park but also provides incubation services ranging from fund raising to legal console. Companies located in these parks can enjoy preferential policies. These parks not only have played an important role in incubating spin-offs created by faculty or students from universities. They have also become a magnet for attracting other hi-tech start-ups including those created by expatriates. According to a report from the Ministry of Education, by the end of 2002, university science parks had attracted US\$ 3600 million in investments, employed 100000 persons in 1200 R\&D centers, supported 5500 hi-tech companies, and incubated 2300 start-ups, among which 920 had graduated and 29 had been listed on the stock exchange (Ma, 2003).

While there is no formal definition, university-affiliated enterprises refer to those enterprises that are in one way or another controlled by the universities they are affiliated with. In reality, some enterprises willingly submit their management control to universities so that they can generate intangible benefit for themselves. University-affiliated enterprises in China are run under three models. The first is university-affiliated factories or print shops, which are mainly used for students to get short-term internship or apprenticeship in a real productive environment. The number of these has been greatly reduced during the past 20 years. The second model is to use university technologies to create joint commercial entities with enterprises outside universities. The most common model is technology development companies created by universities and departments (Li, 2000). 
Since 1985 many university-affiliated factories have opened their doors to the outside world through a more active collaboration with enterprises. Universityaffiliated enterprises (UAES) have been developing at an accelerated speed since 1991 after the endorsement of a guideline for the UAEs by the government. In 1991, sales income of UAES amounted to US\$ 330 million. By 1999, this number reached US $\$ 4.6$ billion. Since 2000, the sales and profits of university-affiliated enterprises have increased steadily.

Table 5

Performance of university-affiliated enterprises 2000-2004 (in million US\$)

\begin{tabular}{ccccccc}
\hline Year & Units & $\begin{array}{c}\text { Total } \\
\text { income }\end{array}$ & $\begin{array}{c}\text { Gross } \\
\text { profit }\end{array}$ & $\begin{array}{c}\text { Net } \\
\text { profit }\end{array}$ & $\begin{array}{c}\text { Yield } \\
\text { of taxes }\end{array}$ & $\begin{array}{c}\text { Profit returns } \\
\text { to universities }\end{array}$ \\
\hline 2000 & 5451 & 5852.1 & 551.2 & 435.3 & 307 & 203.5 \\
2001 & 5039 & 7264.8 & 580.4 & 426.6 & 343.1 & 221.2 \\
2002 & 5047 & 8696.6 & 554.7 & 426.7 & 438.2 & 208.2 \\
2003 & 4839 & 9959.9 & 519.1 & 337.6 & 38.69 & 467.3 \\
2004 & 4563 & 11706.5 & 603 & 356.6 & 48.66 & 587.7 \\
\hline
\end{tabular}

Source: http://www.cutech.edu.cn/ShowArticle.asp?ArticleID=10290

In the year 2004, there were 4563 university-affiliated enterprises based on 592 universities, among which 2355 were in S\&T sectors. In terms of governance structure, 66.71 percent of the university-affiliated enterprises were owned solely by the universities, 32.31 percent were joint ventures with domestic partners and 0.9 percent of them absorbed foreign investment. In terms of management control, 88.34 percent were operated by their universities and another 1.66 percent by departments or institutes within the universities.

Some of the university-affiliated enterprises are publicly traded on the stock market either with their own IPOs or by purchasing "shells" from existing public companies. Till 2003, there have been more than 30 university-affiliated enterprises listed on the stock market and most of them are in the IT industry. Universities are the majority shareholders for some of the enterprises, and for the remainder of them, universities are the largest shareholders, maintaining enough power to control the direction of the companies.

Public universities are not allowed to directly run profit-earning business in most countries. But in China, such activities have been encouraged. As we can see from table 5, the income of the university-affiliated enterprises is amazing. These enterprises not only return a part of their profit to the universities but also continue to serve as the internship training base for students. In 2004, university-affiliated enterprises received 759300 students for internship training. 


\section{The development of China's computer industry}

In the early 80s, the computer industry hardly existed in China. Since the 1990s, China's computer industry has been developing at an accelerated speed. In 1990, the number of PCs produced was only 500 thousand, while in 2003, over 23 million were produced by this country.

Table 6

Growth of PC production (thousand units)

\begin{tabular}{|c|c|c|c|c|c|c|c|c|c|c|}
\hline Year & 1990 & 1995 & 1996 & 1997 & 1998 & 1999 & 2000 & 2001 & 2002 & 2003 \\
\hline Production & 500 & 836 & 1388 & 2066 & 2914 & 4050 & 6720 & 8777 & 14635 & 23167 \\
\hline
\end{tabular}

Source: National Bureau of Statistics of China.

China's hardware industry has been doing very well during these years. In 2002 and 2003, it was the second largest in the world. Although the development of software has not been so fast, it has also been on a rising trend over the years. For the present, the software industry has become a large proportion of China's computer industry, but is still a very small proportion of the country's GDP. The development started accelerating after the promulgation of "Policies regarding the Development of the Software Industry and the Integrated Circuit Industry" in 2000. In 2004, the output of China's software industry amounted to US $\$ 27.8$ billion, with an average increase of $30 \%$ since 1999.

Table 7

Output of software, computer industry and total GDP (million US\$)

\begin{tabular}{lccccc}
\hline & $\begin{array}{c}\text { Output of } \\
\text { software } \\
\text { industry }\end{array}$ & $\begin{array}{c}\text { Output of } \\
\text { computer } \\
\text { industry }\end{array}$ & $\begin{array}{c}\text { Software as } \\
\text { proportion of } \\
\text { computer industry }\end{array}$ & $\begin{array}{c}\text { Total } \\
\text { GDP }\end{array}$ & $\begin{array}{c}\text { Software as } \\
\text { proportion } \\
\text { of GDP }\end{array}$ \\
\hline 1999 & 5319.3 & 20733.9 & $25.60 \%$ & 987951.8 & $0.54 \%$ \\
2000 & 7144.6 & 25903.6 & $27.60 \%$ & 1072289.2 & $0.67 \%$ \\
Growth rate & $34 \%$ & $25 \%$ & - & $8.50 \%$ & - \\
\hline
\end{tabular}

Source: Ministry of Information industry. Yearbook of IT industry, 2002.

According to OECD, China has surpassed the United States to become the biggest exporter of ICт products, including computers, mobile phones, digital cameras, etc. Compared with 2003, China's export of ICT products in 2005 saw an increase of $46 \%$, amounting to 180 billion US dollars, while the growth rate for the us was $12 \%$. China has become a strong exporter of hi-tech products since the year 2002, with a trade surplus of 3 billion US dollars in hi-tech products that year. The most 
recent statistics also indicate that China's PC and laptop trade surplus reached 45.4 billion US dollars in 2004.

The prominent characteristic of China's computer industry may be the strength of its domestic enterprises. Domestic enterprises have strong indigenous innovative capacities, which is not common for developing country. With regard to the hardware industry, although China's domestic enterprises have not possessed an obvious advantage in the production of servers, drivers, and electronic components etc, the PC makers have been performing extremely well in the domestic PC market. Domestic companies had $80 \%$ of the market in 1998 and $75 \%$ in 1999, a remarkable change from the early nineties when foreign companies had $60 \%$ of the PC market (Chung, 1999). Since 2000, the dominance of domestic companies has continued. In 2004, the top three PC market leaders were domestic enterprises, Lenovo (25.1 percent), Beijing Founder Electronics (9.9 percent), and Tsinghua Tongfang (7.8 percent). The fourth was Dell, with a 7.2 percent share of China's PC market, leaving other foreign PC vendors behind, including IBM, which ranked No. 5 with a 5.1 percent share of the market, and No. 6 Hewlett-Packard, which has a 4.8 percent share of the market (Lemon, 2005). In 2005, Lenovo (formerly named Legend) bought the PC division of IBM in a deal valued at $\$ 1.75$ billion, making it the third-largest PC maker in the world after Dell and Hewlett-Packard. Although the strength of China's software industry has still been weak in the world, domestic firms also have their indigenous innovations. The statistics for 2002 shows that domestic software firms held about $33 \%$ of the market (Gartner, 2002).

U/RI-industry linkage: the driving force of indigenous capacity building

The Chinese government's strategy to develop the computer industry is to catch up technologically while maintaining its control over key technologies. The essence of the S\&T reform is to strengthen the U/RI-industry linkage and make China's universities and research institutes directly serve the needs of national economic development. The particular case of China is that not only have university and research institutes been acting as an important provider of technology innovations and the cradle of the future intellectual resources, but they have also commercialized their technology results by operating enterprises, some of which have grown into strong performers in the industry. When we look into the computer industry, we find that almost all the leading domestic companies in this sector are involved with strong U/RI-industry linkage. 
Government influence

Government policies and programs have been the orienting force for the development of high technology in China. Table 9 summarizes the National policies and program. Some of the policies we have discussed in previous sections. The programs worth mentioning here are the "National S\&T Achievements Diffusion Program", "the National Engineering Technology Research Center Program", the "863 Program" and the "Torch Program". The "National S\&T Achievements Diffusion Program" was set to mobilize technological achievements in 1990. In addition, as continued efforts to promote technology transfer and commercialization of research products from academia, measures such as cutting financial support and granting greater autonomy to research institutes from central government, were adopted. The enforcement of "The National Engineering Technology Research Center Program" in 1991 was one of such efforts.

The most important program for the hi-tech areas is the "National High Technology Research and Development Program", or the "863 Program". It covers 20 subject topics selected from eight priority areas: Biotechnology, Information, Automation, Energy, Advanced Materials, Marine, Space, and Laser and Ocean Technology, in which the first six areas are managed by моSт (моsт, 1998). It aims at improving the nation's overall R\&D capability and catching up with the advances of cutting-edge technology in the world. Meanwhile, it also aims at educating and training professionals for the 21st century by mobilizing more than 10000 mass researchers for more than 2860 projects each year (Ito, 1995). Some of the research results in core computer technologies developed by this program became the basis for the leading domestic computer enterprises.

The Torch Program, launched in 1988, eased regulations, provided support for building facilities to attract foreign hi-tech companies, and encouraged the establishment of indigenous hi-tech companies in special zones throughout China. Government planners established these hi-tech zones in close proximity to URIS with the goal of promoting linkages between researchers and firms. Until 2003, 53 national hi-tech zones had been established since 1991. The main industries in these zones were information technology (гт), biotechnology, new materials, and new energy technologies (Annual Report on China's Torch Program, 2003).

Government policies have played a key role in the development of the computer industry. The ninth five-year plan (1996-2000) began to put emphasis on developing the indigenous capacity for China's hardware industry in planning to increase the percentage of domestic components in Chinese-assembled computers and the production of peripherals. "Golden Projects", including "golden bridge", "golden customs", "golden card", were initiated to promote the use of computers and the 
Table 8

Summary of S\&T programs and policies

\begin{tabular}{|c|c|c|}
\hline Policies & Dominant features & Year \\
\hline Key Technology R\&D program & Encouraging efforts in key technologies & 1982 \\
\hline \multicolumn{3}{|l|}{ Resolution on the reform } \\
\hline The sparkle system & Promoting basic research in agriculture & 1985 \\
\hline 863 program & High-tech promotion & 1986 \\
\hline The Torch Program & High-tech commercialization, establishing high-tech zones & 1988 \\
\hline \multicolumn{3}{|l|}{ The National s\&T Achievement } \\
\hline Diffusion Program & Promoting product commercialization & 1990 \\
\hline \multicolumn{3}{|c|}{ The National Engineering Technology } \\
\hline Research Center Program & Technology transfer and commercialization of research products & 1991 \\
\hline The Climbing Program & Promoting basic research & 1992 \\
\hline Endorsement of UAES by SSTCC & Promoting university and industry linkage & 1992 \\
\hline s\&T Progress law & Technology transfer, s\&T system reform & 1993 \\
\hline \multicolumn{3}{|l|}{ Decision on Accelerating S\&T } \\
\hline Progress (сCCP) & Promoting URI-industry linkage & 1995 \\
\hline \multicolumn{3}{|l|}{ The Law for Promoting } \\
\hline \multicolumn{3}{|l|}{ Commercialization of s\&T } \\
\hline Achievement & Regulating the commercialization of s\&T Achievement & 1996 \\
\hline Super 863 Program & Commercialization, break-through in key areas & 1996 \\
\hline \multicolumn{3}{|l|}{ Decision on Developing } \\
\hline $\begin{array}{l}\text { High-tech and Realizing } \\
\text { industrialization (ССCP) }\end{array}$ & High-tech and Realizing & 1999 \\
\hline \multicolumn{3}{|l|}{ The Guideline for Developing } \\
\hline National University Science Parks & Accelerating the development of university science parks & 2000 \\
\hline
\end{tabular}

Source: compiled by the authors based on various sources of MOST.

internet. Though the "golden bridge" project, a national information highway was established. The tenth five-year plan (2001-2005) focused on enhancing innovation capacities, especially in integrated circuit and software technology. More favorable policies were issued during this period. Statistic show that the development of the software industry has greatly been accelerated during that period.

\section{Origins of the Chinese computer industry}

All of the earliest and the most well-known Chinese domestic computer companies have their origins in a variety of sources. Four important modes of IT industry firm formation have been identified by $\mathrm{Lu}(2000)$ :

a) The model of spin-offs from the government-funded research institutes in the Chinese Academy of Sciences (CAS) — as represented by Legend.

b) The model of university-researched technologies being commercialized by private enterprises funded partly by the university and partly by other agents - as represented by Founder and Tongfang, currently the second and the third in the 
PC market, and Dongruan, the first listed software company, which is a university - affiliated enterprise at Dongbei University.

c) The Greenfield startup model — represented by Stone Group Corporation, a company that was started by university graduates at Tsinghua University, whose first products were word-processing products.

d) The model based on spin-offs from a state-run firm, as represented by Great Wall.

All four types of enterprises had their origins in university and research institutions. Let us take those representative companies as examples. Legend started with a number of professors at the CAS Institute of Computing Technology. Founder, China's top university-affiliated enterprise, has roots in Beijing University, developed from the research results of a key government supported research project, font processing and pictographic publishing systems. Stone got started by specifically designing Chinese character software to be combined with a Japanese printer. It also took advantage of talent from CAS, which was crucial to its products. Great Wall was formed by MEI (Ministry for Electronic Industry) for the commercialization of the first generation Great Wall Brand computers, the IBM-compatible PC with superior capabilities for Chinese character generation and a display developed by MEI-affiliate research institutions.

Most of the spin-offs, such as Legend (currently Leonovo) and Stone, have still been working closely with URIS through various kinds of U/RI-linkage, such as technological services contracts, collaborative projects, licensing, etc. Those university-affiliated enterprises, such as Founder of Beijing University, Tongfang of Tsinghua University, and Dongrun Software, continuously build up their innovative capacity by taking advantage of university resources.

\section{The $\mathrm{u} / \mathrm{RI}$-industry linkage model in the computer industry}

The U/RI-industry linkage in the computer industry follows the "triple helix model", which takes the traditional forms of institutional differentiation among universities, industries, and government as the starting point for institutional interaction in the production of knowledge (Etzkowitz and Leydesdorff, 1997). It implies the emergence of new hybrid institutional structures between the three sectors of academia, industry, and government. The government supports the collaboration by setting policies and programs, and putting in place the necessary infrastructure for successful cooperation between URIS and industry. A high level of entrepreneurial activities such as networking, informal and formal connections, and strategic partnerships on the part of universities, which take place in the form of hybrid organizations or coalitions, 
is involved in this model. Based on the institutional level of cooperation, the sphere of cooperation, and the durability of the arrangement, there are 3 major prototypes of collaboration in China: 1) URI-run enterprises; 2) spin-offs, referred to as new, revenue generating firm (i.e., contract and consulting firms, technology asset firms, product-oriented firms) originating from a parent university or research institute (Steffensen et al., 2000); 3) strategic research alliances (i.e., technical service contracts, science parks, think tanks, research groups, etc.).

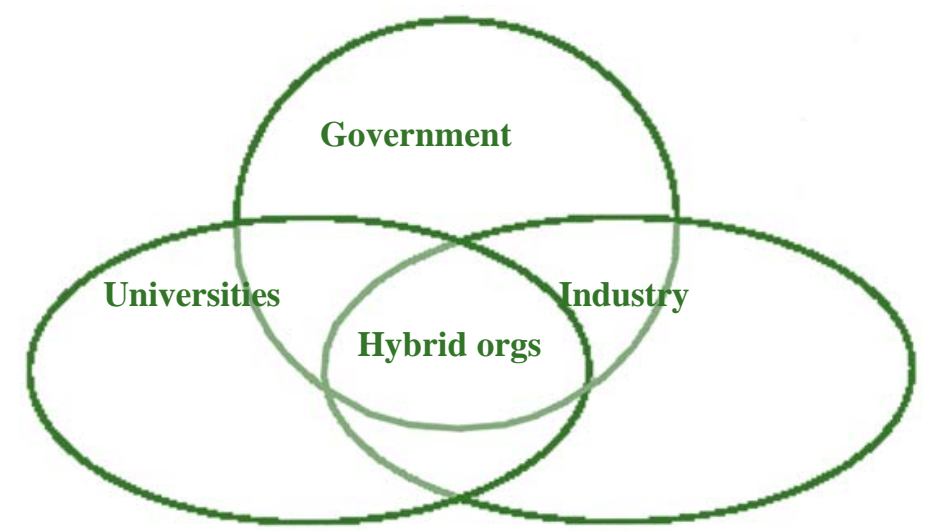

Source: compiled by the authors.

During the S\&T reform, many research institutes and universities have established their own enterprises in hi-tech sectors, most of which acted as commercialization mechanisms for their S\&T achievements. The common practice is as follows: a group of researchers conduct research projects or programs; when they make valuable achievements, they form enterprises to commercialize their products. Such enterprises are generally URI-affiliated at the initial stage. The institutes they belong to make the crucial decisions and share the profits of the enterprises. Later on, when the enterprises grow, de-linkage may take place. They look for other outside investors or get listed on the stock market. Informal relations are generally maintained between the institutes and the enterprises in terms of R\&D support, intellectual resources, etc. Government has played the role of lubricant to facilitate the development of such enterprises. As to intellectual property rights, these stipulate that if the S\&T results of the government supported projects are not concerned with national safety, the property rights belong to the researchers themselves. Moreover, favorable policies, such as tax exemption and money premiums, are offered to URI — run companies and spin-offs in hi-tech sectors. 
In the following sections, we shall investigate the two cores of origin for China's computer industry: the Chinese Academy of Science, the most important research institute in China, and Beijing University and Tsinghua University, China's most prestigious universities.

CAS and its spin-offs

The Chinese Academy of Science (CAS) is a system of government science \& technology research institutes with premises all over China specializing in various areas, the most important ones being located in Beijing. Currently it has 108 institutes, more than 200 hi-tech enterprises and another 20 supporting agencies.

CAS is the highest academic research institute in science \& technology in China and the comprehensive R\&D center for natural science and cutting-edge technology. Founded in 1949, it was formerly the leading agency for defense-related research on nuclear weapons, satellites, and jet-propulsion technologies. In the 1980s, CAS maintained basic research as its major concern while shifting towards R\&D with greater commercial applications. During the S\&T reform, many CAS institutes have been restructured and transformed into enterprises, most of which have entered the hi-tech sectors. CAS (Beijing) established a holding enterprise, the China Science Group (holding) Corporation (CSGC) in 1993. Since then it has been engaged in the management and administration of the assets of cas in order to give free rein to the technological strength achieved by the scientists and experts of CAS and to promote the integration of science and the economy. CSGC now has 30 solely —or partiallyowned membership enterprises. In 2002, the CAs Holding Corporation was established by CAS to be responsible for all its wholly —or partially-owned enterprises. CAS Holding Corporation owns CSGC and another 18 companies and it also has shares in another 6 enterprises, including China's top PC company —-Leonovo. All of the 25 enterprises are engaged mainly in the high technology sectors. CAs has by far the most successful research institute in spinning-off enterprises. Until 2004, the whole CAS system has invested in and spun off more than 400 hi-tech enterprises, eight of which have been publicly listed. The gross income of the enterprises CAS invested in came to US\$ 6.45 billion in 2003 and they had a net profit of US\$250 million.

One of the most successful companies to emerge from CAS was the Lenovo Group Limited (formerly called Legend). It was founded by eleven scientists at the CAS Institute of Computing Technology in Zhongguancun (ZGC, China's so-called "silicon valley") in 1984 with the advanced PCD technology developed at CAS. The founders remained institute employees and CAs provided technologies, a loan of $200000 \mathrm{RMB}$, and office space, as well as research facilities. The decision to start Lenovo in ZGC was sparked by a government initiative to reform the national S\&T 
system giving rise to non-government S\&T enterprises (Lu, 2000). In 1994, Lenovo was listed on the Hong Kong Stock Exchange and became the world's fifth largest supplier of computer motherboards and add-on cards (Lazonick, 2004). Since 1996, Lenovo has become the largest Chinese IT company and occupied first place in China's PC sales market. With its 2005 acquisition of IBM's PC business, Lenovo has become the world's third largest PC firm in terms of sales.

The development of Lenovo is a process of indigenous innovation. In 1987, Lenovo developed its Legend Chinese-character card, which was a great technology breakthrough and won the highest National s\&T Programs Award in China; in 1990, Lenovo launched its first Legend PC in the market and changed its role from an agent importing PCs to a PC producer; in 1995, Lenovo introduced its first Legend brand server; in 1996, Lenovo developed its first Legend brand laptop; in 2002, Lenovo launched its super computer, Deepcomp 1 800, and one year later, Lenovo innovated it into Deepcomp 6800 , ranking $14^{\text {th }}$ on a list of the 500 fastest computers in the world. Lenovo's continuous indigenous innovation capacity has its roots in CAS. CAS has supported Lenovo with preferential treatment including full autonomy in managerial decision-making, financial budgeting, and employee recruitment, and full access to CAS resources. Though CAS owns a controlling interest in Lenovo, Lenovo is independent in conducting business. The benefit for CAS is that Lenovo makes payments to it every year. The relationship between the two is quite close and rather informal.

The case of Lenovo points to the combined strength of the enterprise, the government and the research institute. The government paves the ways for the enterprises and the research institute supports it with available resources. The enterprise model is a symbiosis between the system of scientific research and the system of technology commercialization. More significantly, the success of Lenovo set a model and inspired other research institutes and researchers within the CAS system to establish spin-off companies. This has become particularly important for S\&T development in China.

\section{Universities and their affiliated enterprises}

During China's S\&T reform, universities have become the key force in the national innovation system, not only in educating future intellectuals but also in commercializing science \& technology. According to statistics for the year 2004, 592 of all the 1010 universities in China have established UAEs, with a total of 4563 , including 2355 hi-tech enterprises. Actually, there have been serious concerns about the ownership of the university-affiliated enterprises and the impact of commercialization activities on the function of the university throughout these years. Consequently, 
after 2000, the government and universities have been exploring ways to clarify the complicated relationship involved in the governance structure of the universityaffiliated enterprises and putting more emphasis on patenting licensing and university science parks. But despite all the problems, we should not deny that universityaffiliated enterprises have made a unique contribution to the development of hitech industry in China.

Certainly, not all university-affiliated enterprises are successful, but there are some really successful ones. As we can see from table 10, among the top 10 universityaffiliated enterprises, 7 are in the Iт sector. Founder Tech and Tsinghua Tongfang have remained the market leaders in China's PC market since 2000. On the ranking of China's best IT enterprises (based on sales income) in 2005, Founder Tech and Tsinghua Tongfang occupied 11th and the 25th place, respectively. Dongruan Tech, the first listed software company in China, developed from a university workshop of 3 people with registered capital of just US\$ 5660 in 1991 — currently, it is the leader of the software industry with total assets of US\$30 million.

Beijing University and Tsinghua University have been the leaders, not only in education and research in China, but also in developing the university-affiliated

Table 9

Top 10 high-tech UAE with highest net profit in 2004

\begin{tabular}{|c|c|c|c|c|}
\hline \multirow{2}{*}{$\frac{\text { Ranking }}{1}$} & \multirow{3}{*}{$\begin{array}{l}g \quad \text { Name } \\
\text { Founder Tech } \\
\text { Dongruan Group Ltd }\end{array}$} & \multirow{2}{*}{$\begin{array}{l}\text { Line of industry } \\
\text { IT-high tech R\&D }\end{array}$} & \multirow{2}{*}{$\begin{array}{c}\Lambda \\
\text { University tho } \\
\text { Beijing University }\end{array}$} & \multirow{2}{*}{$\begin{array}{r}\begin{array}{l}\text { Net profit (in } \\
\text { ousand US\$) }\end{array} \\
48336.10\end{array}$} \\
\hline & & & & \\
\hline 2 & & IT-software System integration & Dongbei University & 30898.80 \\
\hline 3 & Tsinghua Tongfang & IT products and services & Tsinghua Unniversity & 13964.90 \\
\hline $\mathrm{Ka}$ & Kaidi Electric Corporation & Electrical equipment & Wuhan Unviersity & 12269.20 \\
\hline 5 & Fudan Engineering & IT products \& services & Fudan University & 11031.60 \\
\hline 6 & Yongsheng Huaqing & IT equipments & Tsinghua University & 10428.00 \\
\hline 7 & Tsinghua Holding & IT products and services & Tsinghua University & 8538.40 \\
\hline 8 & $\begin{array}{c}\text { Sifang Tongchuang } \\
\text { Equipment }\end{array}$ & Electrical equipment & Huabei Electric University & 8012.00 \\
\hline 9 & $\begin{array}{l}\text { Shenzhen Tsinghua } \\
\text { Research Institute }\end{array}$ & Education & Tsinghua University & 7375.20 \\
\hline 10 & $\begin{array}{l}\text { Beijng Jingdian } \\
\text { Technology }\end{array}$ & IT products & Tsinghua University & 7098.00 \\
\hline
\end{tabular}

Source: complied by the authors from http://www.cutech.edu.cn 
enterprises. Founded in 1898, Beijing University is China's first national comprehensive university and the most prestigious university in terms of science and the humanities. Tsinghua University, on the other hand, is China's most famous university for its engineering education and research. The two universities are ranked first on the list of China's best universities. As the most comprehensive university in China, Beijing University has a strong endowment of talent and research resources. It has 12 national core laboratories in different areas, 2 national engineering research centers, including one software research center, and 13 Ministry of Education core laboratories (General Administration Office, 2006). During the S\&T reform, Beijing University has actively involved itself in collaboration with industry and has established firms to commercialize its R\&D achievements. Currently, Beijing University has 9 fundamental affiliated enterprises concentrating in areas of IT manufacturing and services, bioengineering and education, including one Science Park, plus more than 100 medium and small enterprises. It has become a cluster of generating S\&T achievement, incubating hi-tech enterprises and nurturing high-quality intellectuals.

Let us look at the case of Beijing University's most successful affiliated enterprise, the Founder Technology Group. Like most other university-affiliated enterprises active in hi-tech sectors, the emergence of Founder was a research-based achievement developed at the university's laboratory. Founder was the commercialization mechanism for the advanced research result of a government-led R\&D project, the pictographic language electronic publishing system. Established in 1985, listed on the stock market in 1998, Founder currently is the largest university-affiliated enterprise in China with total revenue of USD2.66 billion in 2004. It has been dominant in the market for Chinese-language electronic publishing systems in Asia, the US and Europe. Besides continuously developing its advantage in electronic publishing technology and expanding its business in other area of IT manufacturing and services, Founder also has entered other sectors based on the resources of Beijing University, including medicine and securities investment, etc. Another important Beijing University-affiliated enterprise, Jadebird Corporation, has followed the same route. Its emergence was based on another important government-led R\&D project, “Jade Bird Computer Aided Software Engineering". Established in 1994 with a registered capital of US \$ 700 000, Jadebird Corporation has developed itself into one of the top software companies in China and a comprehensive industrial group covering areas including software technology and services, education and communications.

Most university-affiliated enterprises act as the commercialization mechanism of the R\&D results of the universities. As in China's case, since the absorptive capacity 
of domestic companies has been low, it has been very hard for the universities to find appropriate partners to bring the technology to product. The institutional arrangement of university-affiliated enterprises makes it convenient to bring tacit knowledge gained at the research stage (such knowledge is sometimes the key to success, especially in hi-tech production processes) to the manufacturing stage. We could say that without the university-affiliated enterprises, many R\&D results would never be commercialized.

\section{Conclusion}

In early studies by economists, the scientific knowledge generated from academic research is assumed to be exploited by industrial firms at almost no cost (Nelson, 1959; Arrow, 1962). The argument has been challenged in recent year. Studies by Rosenberg(1982), Mowery(1983), Pavitt(1987), and Cohen and Levinthal (1989) show that transferring scientific knowledge is a costly process, heavily influenced by the division of labor among different institutions in an innovation system, the internal networks and coordination. In another important paper, Cohen and Levinthal (1990) indicated that the "absorptive capacity", the ability of a firm to recognize the value of knowledge, assimilate it and apply it to commercial ends is critical to its innovative capabilities and essential to enterprises in hi-tech sectors. They point out that the absorptive capacity is largely a function of the firm's level of prior related knowledge.

The in-house R\&D capacity of China's domestic enterprise had been very low before 1995. They lacked the necessary intellectual, capital and technical resources to carry out innovations. Before the emergence of those important URI-affiliated enterprises in this sector, there only existed medium and small companies that manufactured low value-added components using low-cost assembly. When research institutes and universities developed S\&T results, the most effective way to make them productive was to transfer them into products and commercialize their S\&T achievement themselves, which is especially evident in hi-tech sectors, such as the computer industry. This is partly because it was difficult to find adequate enterprises to commercialize the knowledge and partly because a critical component of the absorptive capacity for certain types of information such as those associated with product and process innovation is often "team-specific" and therefore cannot easily be transferred and quickly integrated into another firm, while for the commercialization of innovations in the computer sector, such absorptive capacity is crucial. As Lee and Allen (1982) pointed out, considerable time lags are associated with the integration of new technological staff, particularly those concerned with process and product development. To integrate certain classes of complex and sophisticated 
technical knowledge successfully into the firm's activities, the firm requires an existing internal technology staff who are both competent in their fields and familiar with the firm's idiosyncratic needs, organizational procedures, complementary capacity, etc. The institutional mechanism of URI-affiliated enterprises is beneficial for the commercialization of the technology in the sense that the whole research team and tacit knowledge are maintained within the same overall system.

The emergence of successful URI-affiliated enterprises in China's computer industry may be influenced by the interaction of the following factors. Most importantly, S\&T reform has strengthened the U/RI-I linkage and has thus facilitated the development of China's URI-affiliate hi-tech enterprises. It is no exaggeration to say that the research institutes have become the driving force of the indigenous capacity building China's computer industry. In particular, CAS, THU and PKU have been the source of firms that are now among the largest IT suppliers in China. Moreover, Chinese government has adopted a policy of "catching up in technology while maintaining central control over key aspects of economy". The access of foreign companies to China's domestic market was restricted to a certain degree so that the domestic companies have gained time to strengthen themselves (Kenneth and Jason, 2001). Finally, the strong system of the China's URIS combined with the weak inhouse R\&D capacity of its domestic enterprises has strongly impelled S\&Tdevelopments in the computer industry.

Although there have been serious concerns over university-affiliated enterprises, it is undoubtedly the case that university-affiliated enterprises have made great contribution to the growth of China's industry, especially the IT sector. Notwithstanding this, the experience of some successful UAEs suggests that in order to maintain sustainable development, UAEs need to absorb more social capital in the market and clarify the relationship between the government, the university and the enterprise. The solution has been investigated by the government and delinkage has been in progress. The new trend shows that the establishment of science parks and the traditional technology transfer approaches such as licensing may be more appealing in the future.

China's experience shows to what extent government policy can shape the industry. China's strategy of building indigenous innovative capacity by fully exploiting the resources of its universities and research institutes under the suitable orientation of government policy is worthy of study for those developing nations that have strong URIs, but which are weak in in-house corporate R\&D capacity. 
Arora, A., A. Gambardella and S. Torrisi, "In the footsteps of Silicon Valley? Indian and Irish software in the international division of labor", in A. Bresnahan and A. Gambardella (Eds.), Building the Hi-tech Regions, Cambridge, Cambridge University Press, 2004, pp. 78-120.

Arrow, K.J., "Economic welfare and the allocation of resources for invention", The Rate and Direction of Inventive Activity (NBER), Princeton, Princeton University Press, 1962.

Breschi, Stefano and Franco Malerba, "Sectoral innovation systems: technological regimes, Schumpeterian dynamics, and spatial boundaries", in Charles Edquiste (ed.), Systems of Innovation: Technologies, Institutions and Organizations, London, Pinter, 1997.

Bresnahan, T. and A. Gambardella (Eds.), Building Hi-tech Regions, Cambridge, Cambridge University Press, 2004.

Central Committed of the Chinese Communist Party (ссС), Resolution of the Central Committee of the Communist Party of China on the structural reform of the education system, 1985.

Chung, Chin, IT industry in China, "Taipei, Chung-hua Institute for Economics research", Draft of a charter in The Computer Industry, No. 10, 1999.

Cohen, W. and D. Levinthal, "Innovation and learning: the two faces of R\&D", Economic Journal, vol. 99, 1989, pp. 569-596.

, "Absorptive capacity: A new perspective on learning and innovation", Administrative Science Quarterly, 35, 1990, pp. 128-152.

Crow, M. and B. Boeman, Limited by Design: $R \& D$ Laboratories in the US National Innovation System, New York, Columbia University Press, 1998.

Dasgupta, P. and P. David, "Towards a new economics of science", Research Policy, 1994, 23(3), pp. 487-521.

Edquist, C., System of Innovation: Technologies, Institutions and Organizations, London, Pinter, 1997.

Etzkowitz, H. The Second Academic Revolution: MIT and the Rise of Entrepreneurial Science, London, Gordon and Breach, 1999.

Etzkowitz, H.; A. Wester, C. Gebhardt and B. Terra, "The Future of the University and the University for the Future: Evolution of the
Ivory Tower to Entrepreneurial Paradigm", Research Policy, 2000(29), pp. 310-330.

Etzkowitz, H., and L. Leydesdorff (Eds.), Unversities and the global economy: A triple helix of university-industry-government relations, London, Cassell, 1997.

Freeman, C., Technology Policy and Economic Performance: Lesson from Japan, London, Pinter, 1987.

Furman, J.L.; M.E. Porter and S. Stern, "The determinants of national innovative capacity", in Research Policy, 2002(31):899-933.

Goldfarb, B. and M. Henrekson, "Bottom-up versus top-down policies toward the commercialization of university intellectual property", in Research Policy, 2003(33), pp. 639-658.

Gartner, "Comparison: Indian and Chinese Software Services Markets", Gartner research M-16-1762, May 2002.

General Administration Office, "General introduction of Peking University”, January 2006,_www.pku.edu.cn

Ito, S., "Science and technology policy of the People's Republic of China", in The Japan Society for Science Policy and Research Management, 10 (3/4), 1995, pp. 179-185.

Jaffe, A., "The real effects of academic research", in American Economic Review, 1989, 79(5), pp. 957-970.

Kenneth Kraemer and Jason Dedrick, "China's industrial policies and outcomes in the 1990s", in China PC paper for web, June, 2001.

Kenny, M., Biotechnology: The University Industrial Complex, Yale University Press, New Haven, 1986.

Kodama, F. and L.M. Branscomb, "University research as an engine for growth: how realistic is the vision?" in L.M. Branscomb, F. Kodama, and R. Florida (Eds.) Industrializing Knowledge: University-industry Linkage in Japan and the United States, London, MIT Press, 1999, pp. 3-19.

Lazonick, W, "Indigenous innovation and economic development: lessons from China's leap into the information age", in Journal of Industry Studies, December, 2004.

Lee, Denis and J. Thomas Allen, "Integrating new technical staff: implications for acquiring new technology", Management Science, 1982(28), pp. 1405-1420. 
R.R. (Ed.), National Innovation Systems: a

Lemon, Sumer, "Competition heats up for Dell in China's PC market", Infoworld, March 18, 2005, http://www.infoworld.com/article/05/ 03/18/HNheatfordell_1.html

Li, Guoping, A Research Report on the Tenth Five Year Plan for Beijing University $\mathrm{Hi}$ tech Industries, People's Publishing House, 2000.

Liu Yi, "Current situation of China's patent application", Science Daily, January 2,2006, http://www.cutech.edu.cn

Lu, Q., China's Leap into the Information Age, Oxford University Press, 2000.

Lundvall, B., National systems of Innovation: Towards a Theory of Innovation and Interactive Learning, London, Pinter, 1992.

The Ministry of Science and Technology, People's Republic of China (MOST), Annual Report of the State Programs of Science and Technology Development, 1998.

, China New \& Hi-tech Industrialization

Development Report, Science Publishing House, December, 1999.

, China Science and Technology Statistics Data Book, Science Publishing House, 2001.

, China Science and Technology Data Book, Science Publishing House, 2003.

Mowery, D.C., "Economic theory and government technology policy", in Policy Science, 1983.

Mowery, D.C. and N. Rosenberg, "The us national innovation system", in Richard R. Nelson (ed.), National Innovation Systems: A comparative Analysis, Oxford and New York, Oxford University Press, 1993, pp. 29-75.

Ma Wen, "Statistical summary of University Parks 2001-2004", Reform and Strategies, May 2005, http://www.moe.edu.cn

Nelson, R.R., and Rosenberg, N., "Technical innovation and national systems", in Nelson,
Comparative Analysis, Oxford University Press, 1993, pp. 3-21.

, "Technical innovation and national systems", in Nelson R.R. (Ed.), National Innovation Systems: a Comparative Analysis, Oxford University Press, 1993, pp. 3-21.

Nelson, R.R., "The simple economics of basic scientific research", in Journal of Political Economics, 1959

Pavitt, K.L.R., "On the nature of technology", Inaugural lecture, University of Sussex, Science Policy Unit, 1987.

Porter, M.E., and S. Stern, "Innovation: location matters", in MIT Sloan Management Review (summer), 2001, pp. 28-36.

Rappert, B.; A. Webster and D. Charles, "Making sense of diversity and reluctance: academicindustrial relations and intellectual property", in Research Policy, 1999 (28), pp. 873-890.

Rosenberg, N., Inside the Black Box: Technology and Economics, Cambridge University Press, Cambridge, 1982.

Saxenian, A., "Taiwan's Hsinchu region: imitator and partner for Silicon Valley", in T. Bresnahan and A. Gambardella (Eds.), Building Hi-tech Regions, Cambridge, Cambridge University Press, 2004, pp. 190228.

Saxenian, A., Regional Advantage: Culture and Competition in Silicon Valley and Route 128, Cambridge, Massachusetts, Harvard University Press, 1994.

Shane, S.A., Academic Entrepreneurship: University Spin-offs and Wealth Creation, Aldershot Edward Press, 2003.

sstc, Annual Report on China Torch Program, 2003.

Steffenson, M.E., "Rogers M. et al, Spin-offs from research centers at a research university", in Journal of Business Venturing, 15(1), 2000, pp. 93-111. 